\title{
Rancang Bangun Sistem Kontrol dan Monitoring Solar Cell Dengan Raspberry Pi Berbasis Web Sebagai Sarana Pembelajaran di Akademi Teknik dan Keselamatan Penerbangan Surabaya
}

\author{
Prasetyo Iswahyudi \\ Indah Masluchah \\ Program Studi Diploma III Teknik Listrik Bandar Udara \\ Akademi Teknik dan Keselamatan Penerbangan Surabaya \\ Jl.Jemur Andayani 1/73 Wonocolo Surabaya 60236 \\ Telp.(031)841087, Fax.(031)8490005 \\ Email : Prasetyoiswahyudi73@ymail.com
}

\begin{abstract}
ABSTRAK
Rancang Bangun Sistem Kontrol dan Monitoring Solar Cell dengan Raspberry Pi Berbasis Web ini digunakan untuk mendukung proses pembelajaran program studi Teknik Listrik Bandar Udara khususnya yaitu pembelajaran praktek ilmu Sel Surya. Rancangan ini menggunakan Sensor Arus dan Tegangan yang dipasang antara Panel Sel Surya-Charger Controller, Charger Controller -Baterai, Baterai - Beban, serta Sensoer Suhu yang dipasan pada Battery. Pemasangan sensor - sensor ini digunakan untuk mengetahui kondisi arus, tegangan, serta suhu pada rangkaian Sel Surya sehingga dapat mempermudah penjelasan tentang prinsip kerja Sel Surya dalam proses pembelajaran. Hasil pembacaan seksor - sensor tersebut akan diolah oleh Mikrokontroller yang kemudian akan dikirim ke Raspberry Pi unuk ditampilkan melalui Web.

Dalam rancangan alat ini, penulis menggunakan beberapa variabel kontrol antara lain besar Beban yang terpasang dan Intensitas Cahaya sebagai sumber energi dari Sel Surya. Sehingga dapat diketahui perbedaan dan pengaruh variabel kontrol tersebut terhadap hasil pengukuran. Hasil pembacaan dari sensor - sensor tersebut kemudian dibandingkan dengan perhitungan manual sehingga dapat diketahui akurat atau tidaknya data pembacaan sensor.
\end{abstract}

Kata-kata kunci: Solar Cell, Media pembelajaran berbasis web, Intensitas Cahaya, Beban, Sensor Arus dan Tegangan

\section{Pendahuluan}

Sel surya merupakan piranti elektronika yang dapat mengubah energi matahari menjadi energi listrik. Sistem yang menggunakan sel surya ini, tentu membutuhkan baterai untuk menampung energinya. Kendala dalam pemakaian baterai adalah masa pakai baterai yang terbatas. Penyebabnya adalah pemakaian baterai yang tidak terkontrol, serta suhu dan kelembaban yang tidak sesuai oleh karena itu, perlu adanya sistem monitoring penggunaan sel surya. Penggunaan daya pada dan arus pada sel surya dapat diamati dengan web. Pemakaian daya baterai juga dapat diatur berdasarkan parameter daya baterai. Pengamatan daya baterai serta pengaturan pemakaian daya baterai akan didapatkan hasil baterai yang tidak cepat rusak serta kapasitas pengisian yang tetap bertahan lama. Di laboratorium listrik Akademi Teknik dan Keselamatan penerbangan Surabaya terdapat panel sel surya dan baterai sel surya yang difungsikan sebagai media pembelajaran. 


\section{Rumusan Masalah}

Sesuai dengan latar belakang dan batasan masalah diatas, maka rumusan masalah yang akan penulis kemukakan dalam penulisan tugas khusus ini adalah:

1. Bagaimana memonitor sel surya dengan Raspberry $\mathrm{Pi}$ berbasis web sebagai sarana pembelajaran di Akademi Teknik dan Keselamatan Penerbangan Surabaya.

2. Bagaimana mengetahui kerja rangkaian sel surya dengan kontrol intensitas cahaya dan beban terpasang serta pengaruh dari perubahan tersebut terhadap rangkaian sel surya dengan Raspberry Pi berbasis web sebagai sarana pembelajaran di Akademi Teknik dan Keselamatan Penerbangan Surabaya.

\section{Perancangan Alat}

Berikut ini merupakan konsep rancangan alat secara keseluruhan yang nantinya akan penulis buat. Urutan dan perangkat yang akan digunakan akan dijelaskan pada sub bab berikut :

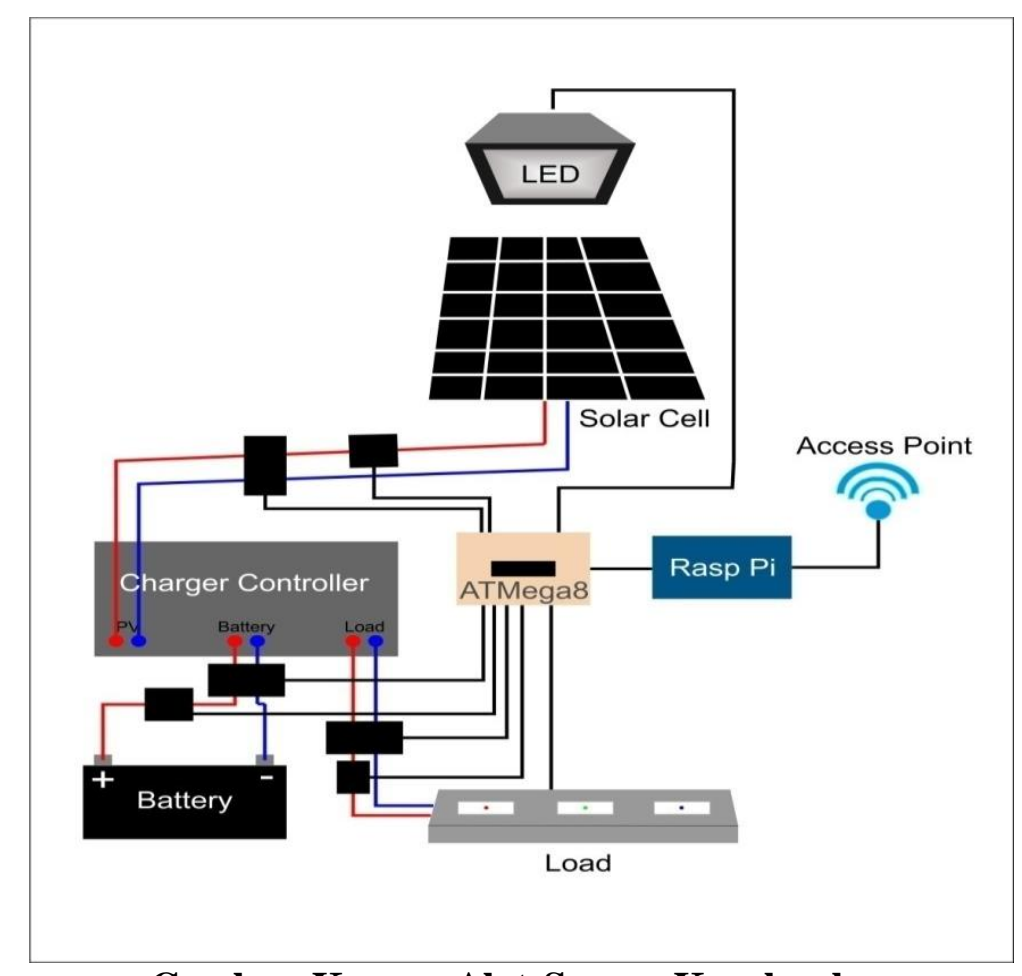

Gambar Konsep Alat Secara Keseluruhan

\section{Prinsip Kerja Konsep Rancangan}

Dalam mewujudkan konsep perancangan kontrol dan monitoring baterai sel surya berbasis web sebagai sarana pembelajaran di Akademi telnik dan keselamatan penerbangan Surabaya yang akan penulis buat maka akan diuraikan perancangan alat dan sistem kerja sesuai dengan ketentuan konsep rancangan. Berikut merupakan blok diagram dari rancangan yang akan dibuat oleh penulis sebagai konsep rancangan. Maksud dan tujuan adanya konsep rancangan ini diharapkan prinsip kerja dari rancangan alat tersebut sesuai dengan kondisi yang diinginkan oleh penulis. Secara keseluruhan blok diagram dijelaskan seperti gambar dibawah ini : 


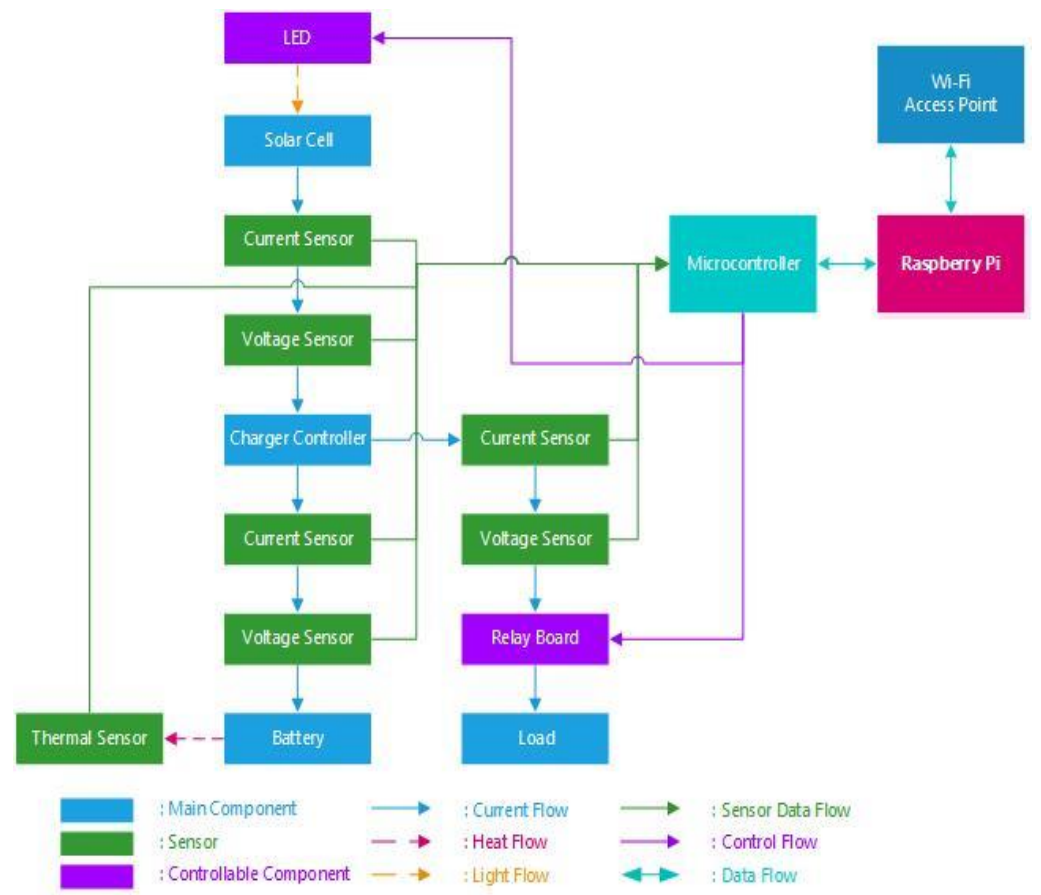

Diagram Blok Konsep Dasar Kontrol Dan Monitoring Baterai Sel Surya Dengan Raspberry Pi Berbasis Web

\section{Sistem Monitoring}

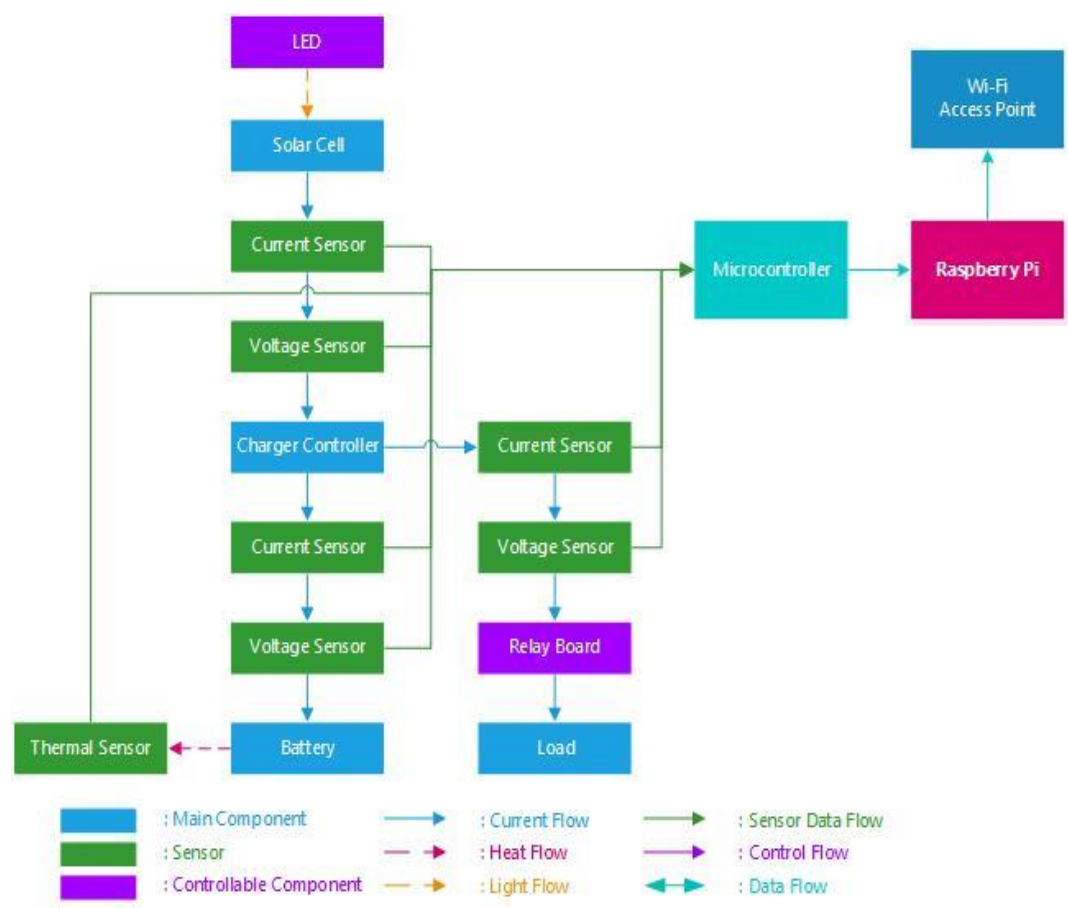

Gambar blok diagram Sistem Monitoring 
Sistem monitoring yang akan digunakan menggunakan Raspberry pi sengan pembacaan data analog oleh sensor diolah menjadi data serial menggunakan mikrokontroller atmega8. Sensor yang digunakan antara lain sensor suhu, sensor Arus ACS712-5 dan sensor tegangan. Sensor arus dan sensor tegangan yang diletakkan di sel surya berfungsi untuk mengetahui arus dan tegangan yang dihasilkan oleh sel surya serta digunakan untuk mengetahui perubahan intensitas cahaya dan pengaruhnya terhadap beban. Sensor arus dan sensor tegangan yang diletakkan di charger controller digunakan untuk mengetahui arus dan tegangan yang masuk dan keluar baterai sel surya. Sensor suhu dan sensor tegangan yang diletakkan pada baterai digunakan untuk mengetahui kapasitas baterai sel surya. Sensor suhu digunakan untuk mengetahui suhu baterai sel surya. Data analog yang dibaca oleh sensor kemudian diolah menjadi data serial oleh mikrokontroller atmega8 dan diproses oleh Raspberry pi yang selanjutnya akan ditampilkan melalui Web.

\section{Sistem Kontrol}

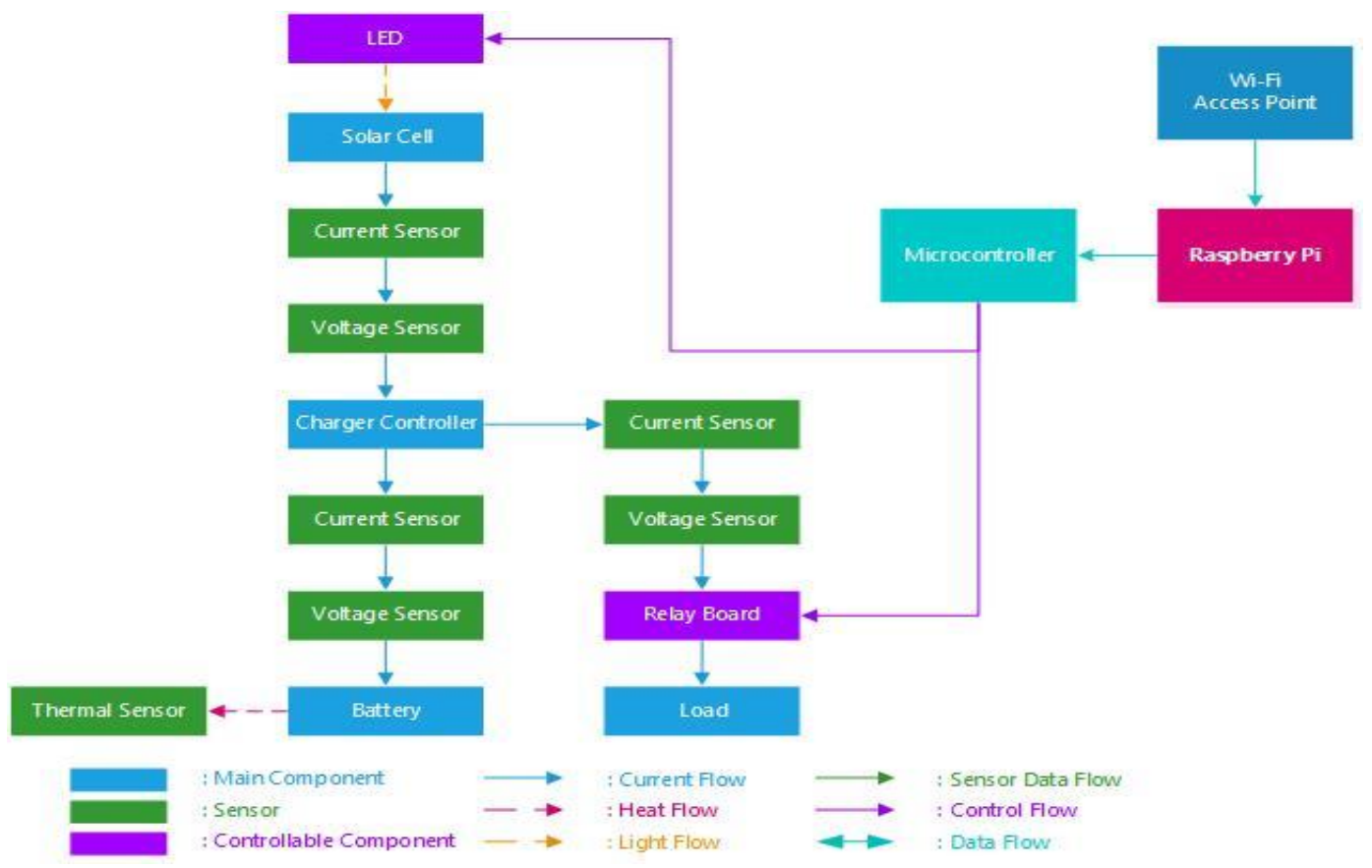

Gambar blok diagram Sistem kontrol

Sistem kontrol yang akan digunakan menggunakan Raspberry Pi, driver PWM (pulse width modulation) untuk kontrol kecerahan lampu LED dan driver relay untuk kontrol penggunaan beban . Dalam hal ini, yang akan dikontrol yaitu intensitas cahaya LED yang digunakan untuk mensimulasikan intensitas cahaya matahari dan banyaknya beban terpasang pada sel surya. Kontrol intensitas cahaya LED digunakan untuk mengetahui pengaruh besar kecilnya intensitas cahaya matahari terhadap rangkaian sel surya serta pengaruhnya terhadap beban terpasang. Kontrol banyaknya beban terpasang digunakan untuk mengetahui pengaruh beban terhadap arus tengangan pada baterai sel surya. 


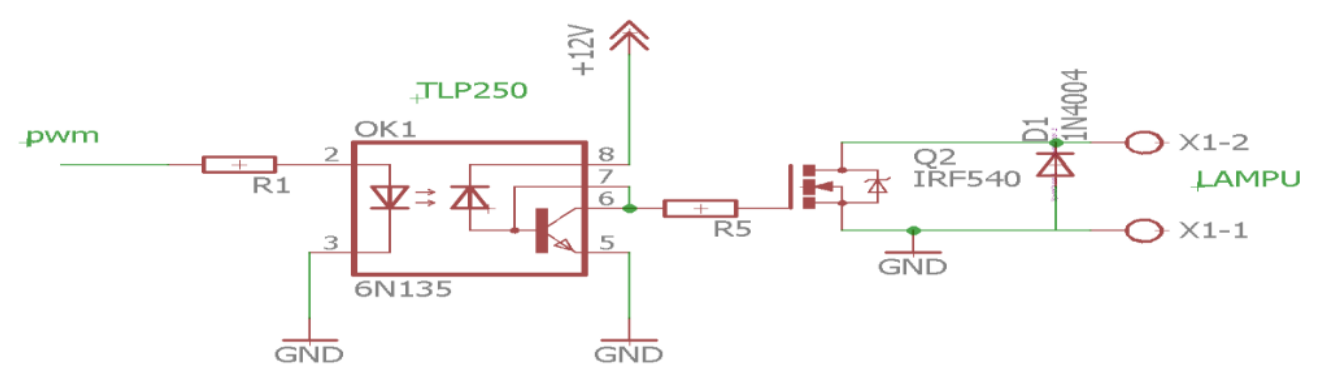

Gambar Driver PWM

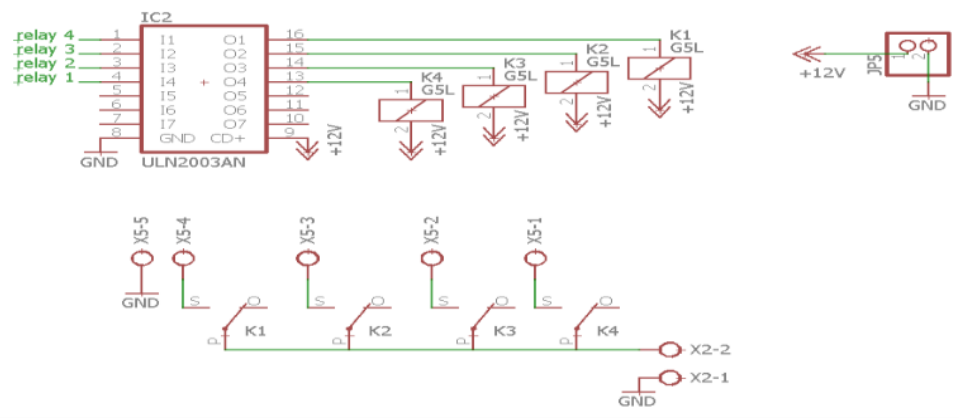

\section{Gambar Driver Relay}

\section{Pengujian dan Analisa}

Pengukuran dan analisa rancangan ini bertujuan untuk memaparkan proses perancangan alat. Dari perencanaan yang dilakukan terhadap alat mulai dari rancangan kerja, rangkaian tiap komponen hingga hasil akhirnya. Perencanaan dan pembuatan alat ini pada dasarnya membutuhkan perancangan dan sistematika yang baik sehingga akan memberikan kemudahankemudahan dalam proses pembuatan alat.

\section{Modul Panel Surya Dan Baterai Charging}

Dalam perencanaannya digunakan panel surya yang memiliki daya $50 \mathrm{WP}$, seperti yang terlihat pada gambar. Panel surya ini terdiri dari 24 sel. Panel ini menghassilkan 12 VDC hingga 16 VDC pada cahaya matahari optimal yaitu sekitar 4,5 sampai 5 jam di siang hari.

\section{Spesifikasi baterai regulator BELL BCR 1012}

\begin{tabular}{|c|c|c|}
\hline 1 & Tegangan keluaran & $12 \mathrm{VDC}$ \\
\hline 2 & Konsumsi daya & $10 \mathrm{~mA}$ (Stand by) \\
\hline 3 & Off charge baterai & $14.50+/-0.01 \mathrm{VDC}$ \\
\hline 4 & On charge baterai & $13.50+/-0.10 \mathrm{VDC}$ \\
\hline 5 & Shut off load & $11.20+/-0.01 \mathrm{VDC}$ \\
\hline 6 & Active load & $12.60+/-0.01 \mathrm{VDC}$ \\
\hline
\end{tabular}




\section{Mikrokontroller}

Pengujian rangkaian mikrokontroler Atmega 8 dan downloader dilakukan dengan cara memasukkan program sederhana, kemudian mengukur tegangan tiap-tiap port. Pengukuran ini bertujuan untuk mengetahui performance dari rangkaian system minimum mikrokontroler, sehingga nantinya dapat mempermudah pengaplikasian dari port-port keluaran mikrokontroler.

Untuk menguji rangkaian mikrokontroler tersebut, maka peril diisi dengan program sederhana dibuat untuk melakukan pengukuran port-port mikrokontroler tersebut bekerja digunakan led sebagai indicator.

\section{Pengujian sensor Arus - Tegangan}

Jenis sensor arus yang digunakan adalah sensor arus type ACS712-5.0. Sensor ini bisa digunakan untuk mengukur arus hingga 5 ampere. Sensor ini dapat memberikan pengukuran arus yang presisi baik untuk sinyal AC maupun DC. Pada sistem ini, arus yang diukur adalah arus DC yang dikonsumsi dari sistem. Pin output sensor ini terdiri dari GND, VCC dan VOUT. Terminal arus dihubungkan pada 2 pin sisi yang lainnya.

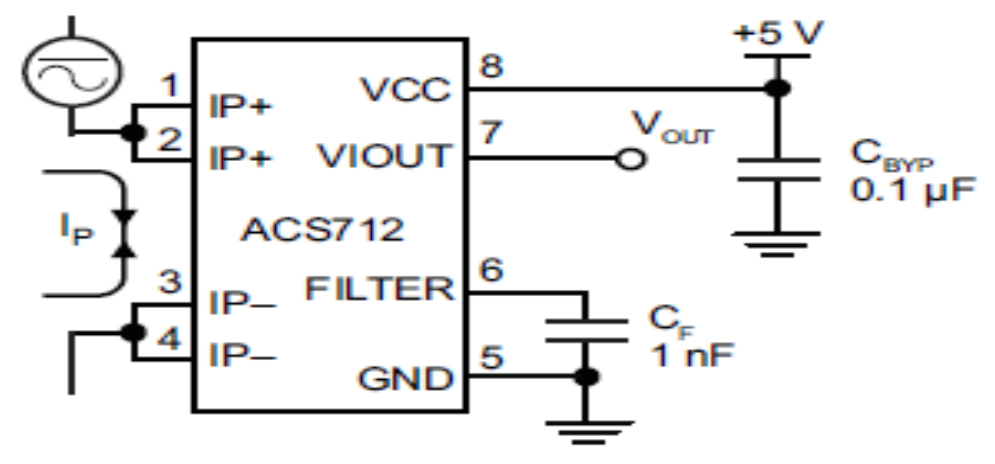

Gambar Sensor ACS-712

Tabel Hasil Pembacaan Sensor Arus dan Tegangan pada Tampilan Web

\begin{tabular}{|c|l|c|c|c|}
\cline { 2 - 5 } \multicolumn{1}{c|}{} & \multicolumn{1}{|c|}{ pembacaan sensor } & \multicolumn{3}{c|}{ Beban } \\
\cline { 2 - 5 } \multicolumn{1}{c|}{ Solar Cell (PV) } & Arus (A) & $\mathbf{2 5 \%}$ & $\mathbf{5 0 \%}$ & $\mathbf{1 0 0 \%}$ \\
\cline { 2 - 5 } & Tegangan (V) & 12,83 & 1,24 & 2,41 \\
\hline \multirow{3}{*}{ Baterai } & Arus (A) & 0,88 & 11,8 & 11,3 \\
\cline { 2 - 5 } & Tegangan (V) & 12,4 & 11,9 & 2,44 \\
\cline { 2 - 5 } & Suhu ('C) & 27 & 27 & 27 \\
\hline \multirow{2}{*}{ Beban } & Arus (A) & 0,84 & 1,26 & 2,23 \\
& & & & 11,3 \\
\cline { 2 - 5 } & Tegangan (V) & 12,3 & 11,8 & \\
\hline
\end{tabular}




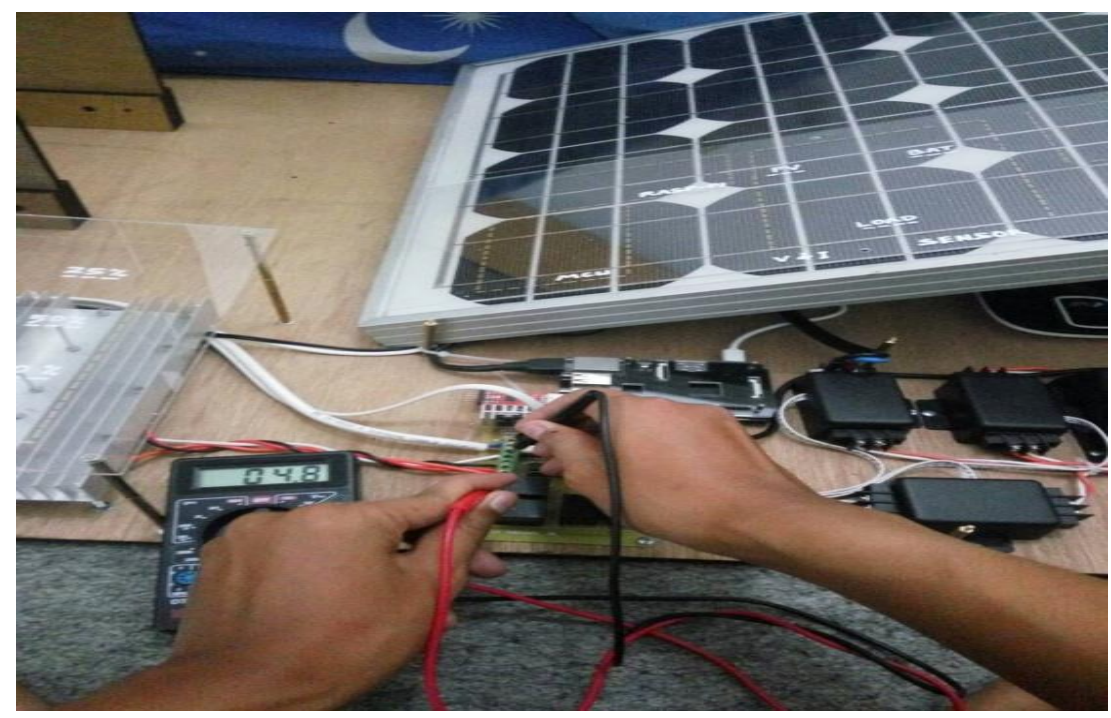

Gambar pengukuran pada beban $100 \%$

1. Pada hasil pengukuran, beban $100 \%$ menunjukkan $\mathrm{R}=4,8 \Omega$,dengan tegangan baterai sebesar 12 volt maka: $\mathrm{I}=\mathrm{V} / \mathrm{R}=12 / 4,8=2,5 \mathrm{~A}$

2. Pada beban $50 \%$, hasil pengukuran menunjukkan $\mathrm{R}=8,1 \Omega$, dengan tegangan baterai sebesar 12 volt, maka : $\mathrm{I}=\mathrm{V} / \mathrm{R}=12 / 8,1=1,48 \mathrm{~A}$

3. Pada beban $25 \%$, hasil pengukuran menunjukkan $\mathrm{R}=14,1 \Omega$, dengan tegangan baterai sebesar 12 volt, maka: $\mathrm{I}=\mathrm{V} / \mathrm{R}=12 / 14,1=0,85 \mathrm{~A}$

\section{Kesimpulan}

1. Perancangan ini difungsikan sebagai inovasi dalam media pembelajaran program studi teknik listrik bandar udara khususnya sebagai mediapembelajaran ilmu sel surya.

2. Rancangan ini merupakan rancangan berbasis web sehingga memudahkan taruna dalam mengakses media pembelajaran tersebut.

3. Rancangan ini digunakan dengan beberapa variabel kontrol antara lain beban dan intensitas cahaya untuk mensimulasikan dengan kenyataan dilapangan pada penggunaan sel surya.

4. Sensor telah dapat membaca data dengan baik sehingga hasil pembacaan Sensor yang ditampilkan pada Web memiliki nilai yang hampir sama dengan hasil perhitungan secara manual.

\section{Daftar Pustaka}

Budiman, arif. DKK. 2010. Generation Of Electricity. Teknik tenaga listrik fakultas teknik Universitas Indonesia.

Pudjanarsa, astu. 2013. Mesin Konvesi Energi. Yogyakarta: Andi.

Yuliarto, brian P.hd .2009. PJU solar cell. ITB.

Raspberry Pi Tutorial. http://duniaelektron.blogspot.co.id/2015/03/raspberry-pi-tutorial.html Pembangkit Listrik Tenaga Sel Surya. konversienergi.eng.unila.ac.id/2015/03/05/pembangkitlistrik-tenaga-sel-surya 